\title{
Merkel Cell Carcinoma cM0 TNM Finding v7
}

National Cancer Institute

\section{Source}

National Cancer Institute. Merkel Cell Carcinoma cMO TNM Finding v7. NCI Thesaurus.

Code C88548.

Merkel cell carcinoma without distant metastasis. (from AJCC 7th Ed.) 